\title{
PELATIHAN DAN PENYULUHAN PENDIRIAN BUMDES DAN KOPERASI PADA KELOMPOK TANI DESA PESISIR BUKIT, KECAMATAN GUNUNG TUJUH, KABUPATEN KERINCI
}

\author{
Ali Idrus ${ }^{1 *}$, Bradley Setiyadi ${ }^{2}$, Denny Denmar ${ }^{3}$, Robin Pratama ${ }^{4}$ \\ 1,2,3,4 Departemen Manajemen dan Ekonomi Pembangunan, Universitas Jambi, Indonesia \\ E-mail: ${ }^{1)}$ Ali.idrus@unja.ac.id
}

\begin{abstract}
Abstrak
Kebijakan pembangunan pertanian diselenggarakan untuk meningkatkan ketahanan pangan, mengembangkan agribisnis dan meningkatkan kesejahteraan petani sehingga produk pertanian yang dihasilkan harus memenuhi syarat kuantitas, kualitas dan berkelanjutan, serta memiliki daya saing dan mudah diperoleh dengan harga yang terjangkau. Potensi yang ada berupa hasil pertanian pangan, perkebunan holtikutura, peternakan serta pengembangan agrowisata perlu dikelola dengan baik melalui keberadaan BUMDes dan koperasi desa. Oleh sebab itu, kegiatan pendampingan, berupa kegiatan pelatihan dan penyuluhan tata cara pendirian BUMDes dan koperasi bagi keberlanjutan pengelolaan hasil pertanian, baik itu pra maupun pasca panen. Pengabdian ini akan memberikan pelatihan dan penyuluhan pada kelompok tani di Desa Pesisir Bukit, Kabupaten Kerinci, agar dapat mendirikan BUMDes dan koperasi untuk meningkatkan hasil komoditi pertanian dan mengembangkan potensi desa. Hasil akhir dari kegiatan pengabdian adalah ini para petani dapat mengelola hasil pertanian dan mengembangkan potensi desa melalui BUMDes dan koperasi sehingga berdampak pada peningkatan taraf hidup
\end{abstract}

Kata kunci: BUMDes, koperasi, potensi desa

\begin{abstract}
Agricultural development policies are implemented to improve food security, develop agribusiness, and improve farmers' welfare so that the agricultural products produced must meet the requirements for quantity, quality, and sustainability, as well as being competitive and easy to obtain at affordable prices. The potential that exists in the form of food agricultural products, horticultural plantations, livestock, and agro-tourism development needs to be managed properly through the existence of BUMDes and village cooperatives. Therefore, mentoring activities, in the form of training and counseling on the procedures for establishing BUMDes and cooperatives for the sustainability of agricultural product management, both pre-and post-harvest. This service will provide training and counseling to farmer groups in Pesisir Bukit Village, Kerinci Regency, so that they can establish BUMDes and cooperatives to increase agricultural commodity yields and develop village potential. The end result of this service activity is that farmers can manage agricultural products and develop village potential through BUMDes and cooperatives so that they have an impact on improving living standards.
\end{abstract}

Keywords: BUMDes, cooperatives, village potential

\section{PENDAHULUAN}

Peningkatan perekonomian desa hendaknya dimulai dengan legalitas yang tepat 
sehingga BUMDes benar-benar membuktikan perannya sebagai salah satu upaya dalam meningkatkan Pendapatan Asli Desa (PADes) serta menumbuhkan perekonomian desa secara utuh dan menyeluruh (Dewi, 2014). BUMDes dapat menjadi lembaga usaha yang produktif, kreatif, inovatif, adaptif dan akuntabel jika inovasi usaha dalam menggali potensi ekonomi sebagai bagian dalam peningkatan taraf hidup didukung dengan SDM pengelolaan lebih profesional (Nursetiawan, 2018). BUMDes memberikan dampak positif bagi masyarakat, khususnya sektor ekonomi lokal berbasis pariwisata namun dalam inovasi pelayanan publik perlu bermitra dengan stakeholder lainnya dan meningkatkan kapasitas SDM (Novandi dan Adi, 2019). Undang-Undang Nomor 6 Tahun 2014 tentang Desa memberikan kesempatan kepada Desa untuk membangun Desa sesuai potensi yang dimiliki dengan mengutamakan partisipatif masyarakat. Salah satu wujud pembangunan penguatan ekonomi desa yaitu melalui pembentukan Badan Usaha Milik Desa (BUMDes) sebagai kelembagan ekonomi desa dalam memanfaatkan dan mendayagunakan sumberdaya lokal dan aset yang dimiliki desa untuk pembangunan berkelanjutan dalam rangka meningkatkan kesejahteraan. Pendirian BUMDes harus diawali sebagai pola untuk memperkuat ekonomi rakyat desa. Embrio ekonomi desa harus terlebih dahulu teridentifikasi secara jelas (Lumintang \& Waani, 2020:15).

Desa Pesisir Bukit, seperti halnya kebanyakan desa lain di Kabupaten Kerinci, memiliki potensi berupa hasil pertanian yang perlu dikelola oleh suatu lembaga seperti BUMDes dan koperasi desa. Hal ini dikarenakan kebijakan pembangunan pertanian diselenggarakan untuk meningkatkan ketahanan pangan, mengambangkan agribisnis dan meningkatkan kesejahteraan petani sehingga produk pertanian yang dihasilkan harus memenuhi syarat kuantitas, kualitas dan berkelanjutan, serta memiliki daya saing dan mudah diperoleh dengan harga yang terjangkau. Potensi yang ada berupa hasil pertanian pangan, perkebunan holtikutura, peternakan serta pengembangan agrowisata perlu dikelola dengan baik melalui keberadaan BUMDes dan koperasi desa. Berdasarkan data yang ada, keberadaan BUMDes di Kabupaten Kerinci sudah merata pada setiap kecamatan. Namun untuk Kecamatan Gunung Tujuh, dari 13 desa yang ada, baru terdapat 6 BUMDes, itu artinya masih ada 7 desa yang belum memiliki BUMDes, salah satunya adalah Desa Pesisir Bukit.

Pemberdayaan dan penguatan kelembagaan petani merupakan proses perubahan pola pikir dengan mempersiapkan sumber daya manusia (SDM) petani menjadi profesional, baik dalam teknis budidaya (produksi), dalam penanganan panen, pasca panen, pemasaran dan pengelolaan organisasi. (Apsari, dkk, 2017:286). Diperlukan kegiatan pendampingan, berupa kegiatan pelatihan dan penyuluhan tata cara pendirian BUMDes dan koperasi bagi keberlanjutan pengelolaan hasil pertanian, baik itu pra maupun pasca panen. Pendampingan dilakukan guna meningkatkan kreativitas petani dalam mengelola hasil alam sehingga memiliki daya jual dan nilai ekonomis yang cukup tinggi, dari hasil komodiri pertanian yang berkualitas. Kegiatan ini dapat dijalankan dengan kegiatan penguatan kelompok tani yang diadakan atas dasar pelatihan dan penyuluhan tata cara pendirian BUMDes dan koperasi desa, guna terjalinnya kerjasama kelembagaan pemerintah dengan masyarakat setempat.

Berdasarkan hal tersebut, maka pengabdian ini akan memberikan pelatihan dan penyuluhan pada kelompok tani di Desa Pesisir Bukit, Kabupaten Kerinci, agar dapat mendirikan BUMDes dan koperasi untuk meningkatkan hasil komoditi pertanian dan 


\section{PORTAL RISET DAN INOVASI PENGABDIAN MASYARAKAT (PRIMA) \\ VOLUME 1 ISSUE 1 (2021)}

mengembangkan potensi desa. Pengabdian ini selain dapat membantu meningkatkan produktivitas hasil pertanian, juga membantu meningkatkan pemahaman dan keterampilan masyarakat petani di Desa Pesisir Bukit dalam pengelolaan hasil pertanian dan pengembangan potensi desa dalam wadah BUMDes dan koperasi.

Berdasarkan uraian permasalahan di atas, maka Pelatihan dan Penyuluhan Tata Cara Pendirian BUMDes dan Koperasi pada Kelompok Tani ini penting untuk segera dilaksanakan dalam rangka mengembangkan keterampilan dan meningkatkan kinerja petani serta pengelolaan hasil komoditi pertanian yang pada akhirnya juga berpengaruh pada peningkatan kesejahteraan petani di Desa Pesisir Bukit, Kabupaten Kerinci. Hasil akhir dari kegiatan pengabdian adalah ini para petani dapat mengelola hasil pertanian dan mengembangkan potensi desa melalui BUMDes dan koperasi sehingga berdampak pada peningkatan taraf hidup para petani di Desa Pesisir Bukit, Kabupaten Kerinci.

\section{METODE PENELITIAN}

\subsection{Urgensi Pengembangan BUMDes dan Koperasi}

Pengembangan BUMDes perlu dilakukan agar BUMDes yang telah berdiri dapat berfungsi sesuai dengan peranannya. Tujuan dan sasaran BUMDes dapat tercapai jika BUMDes dikelola secara terarah dan profesional. BUMDes merupakan solusi atas permasalahan-permasalahan yang terjadi di desa. BUMDes diharapkan dapat mendorong dan menggerakkan perekonomian desa (Ramadana dkk, 2013). Pendirian dan pengelolaan BUMDes adalah merupakan perwujudan dari pengelolaan ekonomi desa yang dilakukan secara kooperatif, partisipatif, emansipatif, transparansi, akuntabel, dan sustainable. Oleh karena itu, perlu upaya serius untuk menjadikan pengelolaan badan usaha tersebut dapat berjalan secara efektif, efisien, profesional dan mandiri untuk mencapai tujuan BUMDes dilakukan dengan cara memenuhi kebutuhan (produktif dan konsumtif) masyarakat melalui pelayanan distribusi barang dan jasa yang dikelola masyarakat dan Pemerintah Desa. (Utami, dkk, 2019:502). Keberadaan BUMDes di desa sangat penting dalam menunjang pembangunan nasional untuk mewujudkan cita-cita bangsa menuju Indonesia sejahtera dan berkeadilan. Pembangunan yang terus dilakukan di pedesaan hingga saat ini telah menunjukkan banyak kemajuan dari berbagai bidang seperti pendidikan, sosial maupun ekonomi. (Sumiasih, 2019:585). Oleh karena itu, pembangunan desa harus menjadi prioritas dalam pembangunan nasional untuk meningkatkan kesejahteraan dan mengentaskan kemiskinan di Indonesia yang salah satunya melalui pembentukan BUMDes dan koperasi desa.

\subsection{Sasaran Latih}

Sasaran latih dari program Pelatihan dan Penyuluhan Tata Cara Pendirian BUMDes dan Koperasi pada Kelompok Tani Desa Pesisir Bukit, Kecamatan Gunung Tujuh, Kabupaten Kerinci adalah warga desa yang memiliki karakteristik sebagai berikut:

1. Pimpinan pemerintahan desa

2. Tokoh masyarakat

3. Petani yang terhimpun dalam Kelompok Tani.

4. Memiliki kemauan untuk mengembangkan diri

5. Bersedia menjalai rangkaian proses pelatihan 


\subsection{Materi Pelatihan}

Materi Pelatihan dan Penyuluhan Tata Cara Pendirian BUMDes dan Koperasi pada Kelompok Tani mencakup pembelajaran teori dan praktek yang mendorong sasaran latih agar dapat mengelola organisasi kelompok tani untuk mengelola hasil pertanian dan mengembangkan potensi desa. Diantara materinya yaitu:

1. Penjelasan mengenai manfaat BUMDes dan Koperasi Desa

2. Pelatihan identifikasi potensi dan asset yang ada di desa

3. Pelatihan penyusunan struktur kepengurusan organisasi BUMDes dan Koperasi Desa

4. Pelatihan penyusunan Anggaran Dasar dan Anggaran Rumah Tangga

5. Pelatihan pembuatan program kerja dan target BUMDes dan Koperasi Desa

\subsection{Narasumber}

Narasumber yang akan memberikan Materi Pelatihan dan Penyuluhan Tata Cara Pendirian BUMDes dan Koperasi pada Kelompok Tani telah memenuhi kriteria sebagai berikut:

1. Memiliki kompetensi dalam mendidik orang dewasa

2. Memiliki etos kerja dan tanggung jawab yang dapat dijadikan panutan bagi peserta latih

3. Diutamakan yang memiliki pengalaman belajar baik secara teoritis maupun praktis

Dari kriteria diatas, diadapatkan beberapa narasumber yang berasal dari berbagai background akademisi dari Universitas Negeri Jambi sebagai penggagas kegiatan pengabdian ini, ditambah Camat Gunung Tujuh dan perwakilan dari PT Alco.

\subsection{Target Luaran}

Target capaian luaran kegiatan Pelatihan dan Penyuluhan Tata Cara Pendirian BUMDes dan Koperasi pada Kelompok Tani Desa Pesisir Bukit, Kecamatan Gunung Tujuh, Kabupaten Kerinci sebagai berikut:

1. Publikasi ilmiah di jurnal prosiding

2. Publikasi pada media massa (cetak/elektronik)

3. Peningkatan omzet pada mitra yang bergerak dalam bidang ekonomi

4. Peningkatan kuantitas dan kualitas produk

5. Peningkatan pemahaman dan keterampilan masyarakat

6. Peningkatan ketenteraman/kesehatan masyarakat (mitra masyarakat umum)

7. Jasa, model, rekayasa sosial, sistem, produk/barang

8. Hak kekayaan intelektual (paten, paten sederhana, hak cipta, merek dagang, rahasia dagang, desain produk industri, perlindungan varietas tanaman, perlindungan topografi)

9. Buku ajar

\section{HASIL DAN PEMBAHASAN}

Membangun masyarakat desa merupakan tugas berat bagi bangsa Indonesia pada saat ini. Lebih dari 50 ribu desa di Indonesia mengandalkan perkekonomian dari hasil pertanian tradisional. Adanya kebijakan pemerintah untuk mengalokasikan dana 1 milyar per desa menjadikan desa sebagai sentral pembangunan. Hal ini diperkuat lagi dengan diterbitkan nya Undang-undang desa yang memberikan keleluasaan pemerintah desa mengelola 


\section{PORTAL RISET DAN INOVASI PENGABDIAN MASYARAKAT (PRIMA) \\ VOLUME 1 ISSUE 1 (2021)}

pemerintahannya sendiri. Kepala Desa, Badan Perwakilan Desa dan apparat pemerintahan desa untuk dapat mengelola desa secara professional sehingga dapat meningkatkan pembangunan sarana dan prasarana fisik dan perekonomian masyarakat yang selanjutanya mempunyai peluang besar dalam mengembangkan potensi desa.

Dalam hal ini tercetus badan yang disebut sebagai BUMDes atau Badan Usaha Milik Desa, salah satu tujuannya adalah untuk mengentaskan kemiskinan dan pemberdayaan potensi desa. BUMDes sebagai badan usaha memiliki modal atau aset yang sebagian atau seluruhnya berasal dari desa. Modal tersebut akan digunakan untuk menciptakan usahausaha dari potensi desa, yang pada akhirnya akan menciptakan lapangan pekerjaan dan peningkatan ekonomi dan kesejahteraan masyarakat. Dalam pengelolaan BUMDes yang baik, pengelolaan modal atau aset harus bisa dijadikan acuan guna mendapatkan keuntungan atau benefit. Dari keuntungan tersebut secara langsung mau pun tidak langsung akan meningkatkan pendapatan desa dan masyarakat desa secara umum.

BUMDes begitu penting bagi desa dan masyarakat, perannya akan begitu membantu dan memberikan manfaat secara langsung. Ketika desa memiliki BUMDes banyak hal yang bisa dibangun guna meningkatkan perekonomian desa. Keberadaan usaha-usaha dalam wadah BUMDes akan menyerap tenaga kerja, terserapnya tenaga kerja akan memberikan pendapatan yang meningkat di masyarakat. Hal tersebut dapat menandai kemajuan desa di berbagai sektor dari potensi yang ada di desa. Guna mencapai hal tersebut, berikut adalah tahapan-tahapan yang dapat dilakukan dalam membangun BUMDes.

\section{Tahap Perencanaan}

Dalam pembentukan BUMDes tahapan pertama yang dapat dilakukan adalah Perencanaan, dalam tahap perencanaan yang harus dikerjakan adalah pembentukan organisasi, menentukan jenis usaha, membuat kerangka usaha. Ketiga hal tersebut harus direncanakan dengan matang dan detail agar badan usaha dapat terwujud dan berkembang dengan baik.

\section{Tahap Pengamatan}

Setelah melakukan tahap perencanaan selanjutnya melakukan pengamatan, pemerintah desa perlu mengamati potensi dan aset desa yang dapat dijadikan usaha BUMDES. Dalam tahapan pengamatan ini sangat penting untuk benar-benar memahami potensi perkembangan usaha yang akan dijalankan melalui BUMDes tersebut.

\section{Tahap Penataan dan Seleksi}

Setelah menyelesaikan tahap pengamatan dan mendapatkan data potensi apa saja yang dapat dijadikan usaha BUMDes selanjutnya perlu melakukan penataan. Hal ini penting karena dalam tahap pengamatan biasanya akan banyak jenis usaha yang muncul, maka kemudian harus dilakukan seleksi dan penataan yang tepat, sehingga dapat diperoleh usaha mana yang paling memiliki potensi dan dapat dijadikan sebagai usaha andalan.

4. Tahap Pemeliharaan

Usaha BUMDes yang telah berjalan harus memiliki pemeliharaan yang baik, hal ini wajib hukumnya karena dana desa yang menjadi modal penggerak harus benar-benar tersalurkan sesuai peruntukannya dan memberikan keuntungan. Pemeliharaan ini meliputi menyisihkan keuntungan untuk keperluan penyusutan peralatan, keperluan teknologi baru dan pemeliharaan umum dari terjaminnya keamanan usaha.

\section{Tahap Pelaporan}


Tahapan kelima adalah pelaporan hasil usaha. Setiap jenis usaha wajib melakukan perhitungan usaha. Baik itu pengeluaran, sampai pemasukan. Dan ini butuh transparansi supaya bisa dilakukan evaluasi. Dalam melakukan usaha apa pun jenis usahanya harus memiliki pelaporan usaha, hal ini berguna sebagai indikator keberhasilan suatu usaha. Dalam membuat pelaporan harus teliti dan adanya transparansi untuk evaluasi dan pertanggung jawaban kepada masyarakat desa.

Demikian adalah tahapan-tahapan yang dapat dilakukan dalam pembuatan BUMDes, dengan menjalankan tahapan-tahapan yang ada maka terwujudnya BUMDes yang berkembang dan sukses akan terlaksana. Kegiatan ini terlaksana selama 4 bulan dimulai dengan tahap perencanaan, pengamatan, penataan dan seleksi, pemeliharaan, dan pelaporan. Pelatihan dan penyuluhan tata cara pendirian BUMDes dan koperasi dilaksanakan pada tanggal 27 Agustus 2021. Pelatihan ini fokus pada kelompok tani dari Desa Pesisir Bukit, Kecamatan Gunung Tujuh, Kabupaten Kerinci. Ditengah pandemi COVID-19, tim pelaksana pelatihan ini tetap memutuskan dating dan memberikan pelatihan secara offline. Pelatihan ini diadakan pada bulan Agustus 2021 dengan beberapa topik pelatihan seperti: (1) Penjelasan mengenai manfaat BUMDes dan Koperasi Desa, (2) Pelatihan identifikasi potensi dan asset yang ada di desa, (3) Pelatihan penyusunan struktur kepengurusan organisasi BUMDes dan Koperasi Desa, (4) Pelatihan penyusunan Anggaran Dasar dan Anggaran Rumah Tangga, dan (5) Pelatihan pembuatan program kerja dan target BUMDes dan Koperasi Desa.

Sesi pelatihan diisi langsung oleh dosen administrasi yaitu Dr. Ali Idrus, M.Pd., M.E.; dosen manajemen yaitu Bradley Setiyadi, S.Pt., M.Pd.; dosen pertanian yaitu Dr. Ir. Denny Denmar, M.P; dan dosen ekonomi koperasi yaitu Robin Pratama, S.Pd., M.Pd. Pelatihan tidak hanya fokus pada kajian ilmu dan teoritis saja tetapi juga bagaimana implementasinya di dunia nyata. Untuk pemaparannya, tim pelaksana menggunakan metode-metode presentasi (presentasi methods) yaitu metode pelatihan dimana orang-orang yang dilatih merupakan penerima informasi pasif. Setiap sesi diberikan kesempatan untuk sesi tanya jawab. Kesempatan itu digunakan oleh kelompok tani di desa Pesisir Bukit belajar dan mencoba mendirikan BUMDes dan koperasi sendiri dalam rangka meningkatkan taraf hidup mereka saat ini dan kedepannya.

Program pelatihan ini sangat penting untuk dilanjutkan secara berkesinambungan. Oleh karena itu, rencana tahapan selanjutnya dari program ini adalah adanya program yang berkesinambungan, terkait pendirian BUMDes dan Koperasi untuk memajukan ekonomi desa 


\section{PORTAL RISET DAN INOVASI PENGABDIAN MASYARAKAT (PRIMA) \\ VOLUME 1 ISSUE 1 (2021)}

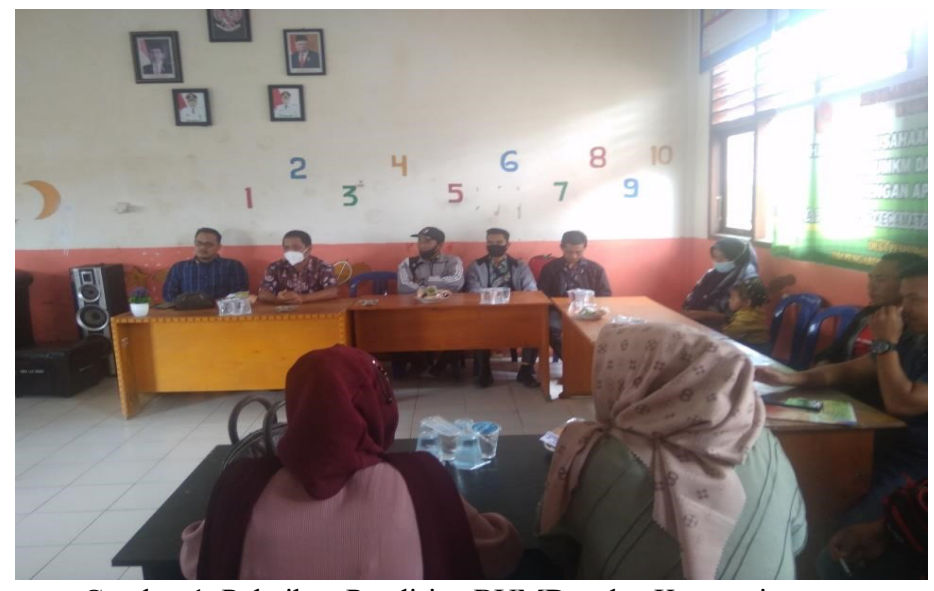

Gambar 1. Pelatihan Pendirian BUMDes dan Koperasi

\section{KESIMPULAN}

BUMDes dan koperasi bagi kelompok tani di Desa Pesisir Bukit, Kecamatan Gunung Tujuh, Kabupaten Kerinci sangat bermanfaat bagi masyarakat desa dan dapat meningkatkan perekonomian desa, maka sangat penting untuk mendirikan BUMDes dan koperasi yang baik dan sesuai dengan potensi yang ada. Dengan menjalankan tahapan-tahapan yang ada maka terwujudnya BUMDes dan koperasi yang berkembang dan sukses akan terlaksana. Manfaat yang dapat diambil dalam kegiatan Pendampingan Pendirian BUMDes adalah (1) dapat meningkatkan pemahaman dan keterampilan petani dalam pengelolaan hasil pertanian; (2) dapat meningkakan produktivitas hasil olahan pertanian baik secara kualitas maupun kuantitas; (3) dapat memberdayakan kelompok tani yang ada sehingga kegiatan yang dilakukan lebih terorganisir; dan (4) dapat memanfaatkan potensi-potensi yang ada di desa melalui pendirian BUMDes dan koperasi.

\section{DAFTAR PUSTAKA}

Anggunggunanto, E.Y., F. Arianti., E.W. Kushartono \& Darwanto. (2016). Pengembangan Desa Mandiri Melalui Pengembangan Badan Usaha Milik Desa (BUMDes). Jurnal Dinamika Ekonomi \& Bisnis Volume 13 Nomor 1 Maret 2016 hal. 67-81.

Apsari, N.C., A.S. Gutama., N. Nurwati., H. Wibowo., R. Resnawaty., R.S. Darwis., M.B. Santoso \& S. Humaedi. (2017). Pemberdayaan Petani Kopi Melalui Penguatan Kapasitas dalam Pengolahan Hasil Kopi di Desa Genteng, Kecamatan Sukasari, Kab. Sumedang. Jurnal Penelitian \& PPM Volume 4 Nomor 2 Juli 2007 hal. 290-296.

Dewi, S.S.K. (2014). Peranan Badan Usaha Milik Desa (BUMDes) Sebagai Upaya dalam Meningkatkan Pendapatan Asli Desa (PADes) serta Menumbuhkan Perekonomian Desa. Jurnal of Rural and Develompent Volume V Nomor 1 Februari 2014 hal. 1-14.

Dinas Perkebunan Provinsi Jambi. (2018). Luas, Produksi dan Petani Perkebunan Kabupaten Kerinci Tahun 2018. Badan Pusat Statistik Provinsi Jambi.

Direktorat Jenderal Pembangunan Kawasan Desa. (2020). Perkembangan Badan Usaha Milik Desa (BUMDes) di Kabupaten Kerinci. Kementerian Desa, Pembangunan Daerah Tertingal dan Transmigrasi.

Handayani, T., A.D. Sore \& Y. Astikawati. (2020). Peran Koperasi dalam Meningkatkan Kesejahteraan Anggota di Koperasi Unit Desa Bale Yotro Desa Beloyang. JURKAMI: 
Jurnal Pendidikan Ekonomi Volume 5 Nomor 2 Tahun 2020 hal. 102-112.

Lumintang, J \& F.J. Waani. (2020). Peningkatan Kapasitas Pengelolaan Badan Usaha Milik Desa (BUMDes) di Desa Koka dan Desa Kembes 2 Kecamatan Tombulu. The Studies of Social Science Volume 2 Issue 1, 2020 pp. 15-21.

Novandi, H.R \& I.R. Adi. (2019). Badan Usaha Milik Desa (BUMDes) Ijen Lestari Sebagai Inovasi Pelayanan Publik Untuk Mendukung Pengembangan Ekonomi Lokal Melalui Community Based Tourism. Jurnal Ilmu Kesejahteraan Sosial Jilid 20 Nomor 1 April 2019 hal. 68-80.

Nursetiawan, I. (2018). Strategi Pengembangan Desa Mandiri Melalui Inovasi BUMDes. MODERAT: Jurnal Ilmiah Ilmu Pemerintahan Volume 4 Nomor 2 Tahun 2018 hal.7281.

Perdana, A.S. (2016). Pemberdayaan Kelompok Tani Melalui Pasar Lelang Sebagai Solusi Mewujudkan Kedinamisan Kesejahteraan Petani. VIGOR: Jurnal Ilmu Pertanian Tropika dan Subtropika Volume 1 Nomor 1 hal. 52-63.

Peraturan Menteri Desa, Pembangunan Daerah Tertinggal dan Transmigrasi Nomor 4 Tahun 2015 tentang Pendirian, Pengurusan dan Pengelolaan, dan Pembubaran Badan Usaha Milik Desa. Berita Negara Republik Indonesia Tahun 2015 Nomor 296.

Peraturan Pemerintah Republik Indonesia Nomor 11 Tahun 2021 tentang Badan Usaha Milik Desa. Lembaran Negara Republik Indonesia Tahun 2021 Nomor 21, Tambahan Lembaran Negara Republik Indonesia Nomor 6623.

Sembiring, A.C., D. Sitanggang., N. Purnasasi \& I. Budiman. (2019). Peningkatan Kesejahteraan Petani Kopi Melalui Pengolahan Pasca Panen di Desa Lingga Kabupaten Karo. Wahana Inovasi Volume 8 Nomor 2 Juli-Desember 2019 hal. 21-27.

Sumiasih, K. (2019). Peran BUMDes dalam Pengelolaan Sektor Pariwisata (Studi di Desa Pakse Bali, Kabupaten Klungkung). Jurnal Magister Hukum Udayana Volume 7 Nomor 4 hal. 565-585.

Undang-Undang Republik Indonesia Nomor 6 Tahun 2014 tentang Desa. Lembaran Negara Republik Indonesia Tahun 2014 Nomor 7, Tambahan Lembaran Negara Republik Indonesia Nomor 5459.

Utami, K.S., L.E. Tripalupi \& M.A. Meitriana. (2019). Peran Badan Usaha Milik Desa (BUMDes) dalam Peningkatan Kesejahteraan Anggota Ditinjau Melalui Kewirausahaan Sosial. Jurnal Pendidikan Ekonomi Volume 11 Nomor 2 Tahun 2019 hal. 498-508. 